\title{
The Relationship between Mental Health, Educational Burnout and Strategies for Coping with Stress among Students: A Cross-Sectional Study of Poland
}

\author{
Piotr Długosz *(i) and Damian Liszka \\ Institute of Philosophy and Sociology, Pedagogical University of Krakow, 30-084 Krakow, Poland; \\ damian.liszka@up.krakow.pl \\ * Correspondence: piotr.dlugosz@up.krakow.pl
}

check for updates

Citation: Długosz, P.; Liszka, D. The Relationship between Mental Health, Educational Burnout and Strategies for Coping with Stress among Students: A Cross-Sectional Study of Poland. Int. J. Environ. Res. Public Health 2021, 18, 10827. https: / / doi.org/10.3390/ijerph182010827

Academic Editors:

Fernando Sánchez-Santed, Maria Teresa Colomina Fosch,

Caridad López Granero and Ingrid Reverte

Received: 13 September 2021

Accepted: 12 October 2021

Published: 15 October 2021

Publisher's Note: MDPI stays neutral with regard to jurisdictional claims in published maps and institutional affiliations.

Copyright: (c) 2021 by the authors. Licensee MDPI, Basel, Switzerland. This article is an open access article distributed under the terms and conditions of the Creative Commons Attribution (CC BY) license (https:// creativecommons.org/licenses/by/ $4.0 /)$.

\begin{abstract}
This study sought to investigate the risk factors of poor psychosomatic health among students during the quarantine of the first wave of the COVID-19 pandemic. A survey was conducted on-line, on a sample of 1978 respondents in Poland. The study was carried out towards the end of the summer 2020 semester. The questionnaire used in the study was designed so that it allows for the observation of the main risk factors which have an impact on the students' mental health. Variance analysis and hierarchical regression analysis were used to determine the predictors of mental health problems. The results indicate that average and high levels of psychosomatic disorders were observed among $61 \%$ of respondents. The hierarchical regression analysis showed that an increase in the level of educational burnout, a decreased life satisfaction, and use of negative strategies of coping with stress, were accompanied by a deteriorated mental condition of students. Moreover, it was observed that female respondents scored higher on the scale of disorders in comparison to males.
\end{abstract}

Keywords: COVID-19; psychosomatic disorders; educational burnout; philosophy of education challenges; coping; students; Poland

\section{Introduction}

The coronavirus pandemic has been described as a perfect storm with a tremendous aftershock of psychosocial and economic effects that cannot be fully discovered and predicted. At the moment, a decrease in the mental and physical health indices and an increase in economic inequalities are expected [1]. The imposition of a lockdown has led to the closing of schools and universities all over the world. It is estimated that approximately 1.5 billion learners-representing $91 \%$ of students in the world-have suffered as a result of the imposition of distance education [2]. Turning to distance learning on a global scale leads to the risk of an increase in educational inequalities and a deterioration of the students' mental health. It is worth bearing in mind that not only do schools have an educational function, but they also provide nutrition and health services, especially those related to mental health. It is estimated that as a result of the closing of schools in the USA, approximately 3 million teenagers got deprived of psychological assistance [3]. This may be the reason for the significant deterioration of the mental health of young people in many countries [4-6].

Studies conducted in many countries indicate that during the quarantine students displayed high levels of stress, anxiety and depression [7,8]. Different studies have also shown that apart from the symptoms of distress, students declared suicidal thoughts, problems with concentration or self-mutilation [9]. In the USA, 71\% of students maintain that during the pandemic they observed an increase in their levels of stress and anxiety [7]. Meta-analyses indicate that $9-54 \%$ of students all over the world experienced psychological distress [8]. 
Analyses have shown that the main mental health risk factors during the pandemic are: being a female [9], living on one's own [9,10], an uncertain financial situation [9], contact with people who contracted COVID-19 [8,9], being in the final year of studies [8,11], lack of social support [9,12], social media exposure [9] and using negative strategies for coping with stress [13]. What is more, studies indicated that being overloaded with distance education has a negative impact on the mental health of youth [11].

The vast majority of studies are of cross-sectional nature and therefore it is impossible to unambiguously determine that the pandemic and its consequences have led to a deterioration of the mental health of young people. Nonetheless, there are results of comparative research that indicate that the mental health of youth has deteriorated during the pandemic [4-6]. There are also studies carried out in Poland with results that confirm a negative impact of the lockdown on young people's mental health. In the age group $18-24,26 \%$ of respondents experienced depression and being unhappy in 2019, whereas $32 \%$ of respondents felt depressed and unhappy in 2020. The feeling of helplessness and fatigue was experienced by $15 \%$ of respondents in 2019 and $44 \%$ of respondents in 2020 . The feeling of fatigue and lack of motivation was declared by $27 \%$ of respondents in 2019 and $47 \%$ of respondents in 2020 [14].

The majority of research conducted thus far on the mental health of youth was carried out among secondary school students [15-17]. This study sought to delve into the situation of students whose lives changed dramatically during the quarantine. They returned to their homes, got deprived of contact with their teachers and friends, and spend long hours in front of their computer screens. Their social lives have been limited significantly as well. Additionally, socio-economic circumstances may have an impact on the mental health of students. One should bear in mind that COVID-19 is a dangerous disease and the fear of it may have a negative impact on the students' health.

The pandemic posed a real threat to one's life and health. While this study was being conducted in June 2020, there were approximately 300 confirmed COVID-19 cases a day. This increased to 700 new cases a day in August, and more than 800 cases a day in September. The second wave started in October 2020 and the number of reported incidences increased to 9000 cases a day [18]. In Poland and in other countries, there has been an increase in deaths as a result of COVID-19. The COVID-19 mortality rate was $2.2 \%$ [19]. In June 2020, around 820 people per million inhabitants had been diagnosed as infected, as compared with the following numbers of cases per million in other countries: USA, 6900; Belgium, 5200; UK, 4400; Italy, 3900; but only 280 in neighboring Slovakia [20].

Moreover, the economic context is important, as the lockdown might have led to an economic crisis and a decrease in the sense of economic security. This is evident in the research showing that in Poland young people suffered the most during the lockdown. Research shows that while $9 \%$ of Poles experienced a reduction in employment and had to limit their economic activity, $11 \%$ of young people aged 18-24 were forced to limit their economic activity and suffered a reduction in employment. Moreover, $3 \%$ of Poles lost their jobs during the lockdown, and $10 \%$ among young people. The situation was similar with reduced hours at work. Among the total number of respondents, working time limitations affected $20 \%$ of Poles, and among young people, it was $28 \%$ [21]. It was even more difficult for youth in the United States, wherein the age group of 16-24 the unemployment rate has increased from 8\% in January 2020 to $25.3 \%$ in April 2020 [22].

Moving on to the conducted research, it is worth emphasizing that the aim of the research was to check the psychosomatic condition of students who had participated in distance education for several months. The study was meant to answer the question of whether the pandemic and distance education have a negative impact on the mental health of adolescents.

It is assumed that the main factor negatively influencing the mental health of students is being exhausted from distance education. The higher the level of educational burnout, the worse the psychosocial condition of students. The strategy for coping with stress may also determine the students' psychological condition. In the case of using emotion- 
focused strategies, a deterioration of mental health may occur. Socio-demographic features influence one's psychosomatic condition to a lesser extent.

\section{Methods}

\subsection{Sample}

This cross-sectional study was conducted using a Computer-Assisted Web Interview to assess mental health problems. The research survey was conducted on-line between the 1 June 2020 and the 10 June 2020. The questionnaire was placed on the LimeSurvey platform. The study was conducted by the end of the summer semester on purpose, in order to determine the impact of distance education on the students' mental health in more depth. The survey was conducted on a sample of 1987 students of the Pedagogical University of Kraków. In Kraków, there are 21 universities, in which more than 150,000 people were studying in the 2019/2020 academic year, of which the Pedagogical University of Kraków numbered around 10,000 students.

A non-random sampling method was used in the study. Convenience sampling was based on the availability of surveyed students. The respondents were selected by means of sending a link to the survey. The study was voluntary and anonymous. All procedures were conducted in accordance with the ethical standards of the Helsinki Declaration of 1975, as revised in 2008.

The questionnaire included questions regarding the following demographic factors: gender, personal evaluation of one's financial standing, place of birth and place of residence during the time of this research study, university major, year of studies, social status, religiosity and university grades. In the study, attitudes towards the pandemic, satisfaction with life and strategies for coping with stress were measured as well.

\subsection{Measured Variables}

\subsubsection{The Scale for Measurement of Psychosomatic Disorders (HBSC-SCL)}

The scale used to measure health disorders was derived from the HBSC-SCL research [23], which was modified for the purpose of the Polish HBSC research [24] and adapted to the research at hand. The following eight symptoms were measured: headache, stomach ache, dizziness, trouble sleeping, nervousness, gloom, bad mood, fatigue and irritability. The intensification of symptoms in the last 7 days was evaluated using an ordinal scale, which was developed by the authors of the research. The responses are as follows: yes, several times-4; yes, a few times-3; yes, 1-2 times-2; I haven't felt-1. The Cronbach reliability score was $\alpha=0.864$.

\subsubsection{Educational Burnout}

Educational burnout was defined as exhaustion due to stress and pressure which stem from the tasks and duties fulfilled by the students in their school and educational classes [25] This research used the LBQ Link Burnout Questionnaire [26] in the Polish version [27]. The questionnaire was adapted to the needs of the present research on educational burnout during distant learning. The scale used for measuring educational burnout had 16 items. The measurement was based on a five-point Likert scale, ranging from "I strongly agree" to "I strongly disagree." The Cronbach reliability score was $\alpha=0.890$.

The respondents were also asked for the evaluation of distant learning conducted within their major. The scale consists of the following answers: 1—very good, 2-good, 3-average, 4-bad, 5-very bad.

\subsubsection{Strategies for Coping with Stress}

The construct put forward by Lazarus and Folkman [28] was used to measure the strategies for coping with stress. Its Polish version was used in the research conducted among students [29]. Dominant strategies were distinguished by means of factorial analysis. The problem-focused stress coping strategy included the following responses: (1) I ask 
other people for help and advice; (2) I get mobilized and do my best to protect myself from stress; (3) I comfort myself with a thought that it could have been worse, but at the moment I am healthy; (4) I pray to God for help; (5) I focus on different things which divert my attention and improve my mood. The emotion-focused strategy was indicated by the following responses: (1) I use alcohol, drugs, other psychoactive substances; (2) I give up, don't know what to do and what to expect; (3) I take sedatives.

\subsubsection{Financial Stress}

Financial stress was measured by means of a question of whether the COVID-19 pandemic led to a deterioration of one's financial standing: definitely yes-1, yes-2, no-3, definitely not -4 , hard to say -5 .

\subsubsection{Satisfaction with Life}

Satisfaction with life was measured using the following ordinal scale: very satisfied-1, rather satisfied -2 , rather dissatisfied -3 , very dissatisfied -4 , and hard to say -5 .

\subsubsection{Attitudes towards the Pandemic}

The level of interest in the pandemic was measured using the following ordinal scale: highly interested -1 , rather interested -2 , rather not interested -3 , and not interested at all-4.

The respondents were also asked whether the pandemic poses a serious threat for them: 1 -yes, it poses a serious threat, 2 -it poses a minor threat, 3 -it does not pose a threat, 4-hard to say.

The attitude towards the government was measured as well. The respondents were asked whether the government and relevant services undertook satisfactory measures in order to protect the country from the coronavirus epidemic or not: $1-$ yes, they do enough, 2- no, they don't do enough, 3- hard to say.

All statistical analyses were conducted using SPSS Statistics version 25. Firstly, we conducted a descriptive statistical analysis of the scale of psychosomatic disorders. Secondly, we assessed associations between demographic data and other variables, which were measured with the HBSC-SCL scale by using the analysis of average values. Finally, a hierarchical regression analysis was used in order to identify the most relevant risk factors determined in the study, taking into account the social and economic contexts.

\section{Results}

On the applied HBSC-SCL scale of psychosomatic disorders, the result of 18.3 was obtained $(S D=5.6)$, median $=18$, and dominant $=17$. The minimum value on the scale was 8 , and the maximum value was 32 . Considering the obtained results, the students may be divided into three categories: those who had low levels of psychosomatic disorders-score: 8-16 (39\%), medium levels-score: 17-24 (46\%), and high levels-score: 25-32 (15\%).

The results of the conducted analyses indicate that $\frac{3}{4}$ of students had health problems and experienced internalizing disorders by the end of distance education.

Table 1 presents how independent variables influence the value of average results on the HBSC-SCL scale. Female students, those who evaluate their financial status as poor, the students of first-cycle and long-cycle master's degree studies, those with lower social status and non-believers as well as undecided in terms of faith had worse psychosomatic health The most significant differences were observed in the case of educational burnout. A high level of educational burnout; bad evaluation of distance education; passive, emotionfocused adaptive strategy, financial stress, lack of satisfaction with life, fear of contracting coronavirus and negative evaluation of activities undertaken by the government intensified the risk of a bad psychosomatic condition. 
Table 1. Relationship between independent variables and mental health.

\begin{tabular}{|c|c|c|c|c|c|}
\hline & & $\mathbf{n}$ & $\mathbf{M}$ & SD & \\
\hline \multirow{2}{*}{ Gender } & Male & 321 & 16.2 & 5.8 & \multirow{2}{*}{$\begin{array}{c}\mathrm{F} \text { value }=60.3 \\
p \text { value }=0.000 \\
\eta^{2}=0.031\end{array}$} \\
\hline & Female & 1593 & 18.8 & 5.4 & \\
\hline \multirow{3}{*}{ Financial standing } & Bad & 323 & 20.3 & 5.4 & \multirow{3}{*}{$\begin{array}{c}\mathrm{F} \text { value }=24.3 \\
p \text { value }=0.000 \\
\eta^{2}=0.025\end{array}$} \\
\hline & Average & 1279 & 18.0 & 5.5 & \\
\hline & Good & 307 & 17.7 & 5.7 & \\
\hline \multirow{4}{*}{ Place of residence } & Village & 816 & 18.1 & 5.5 & \multirow{4}{*}{$\begin{array}{c}\mathrm{F} \text { value }=1.18 \\
p \text { value }=0.314 \\
\eta^{2}=0.002\end{array}$} \\
\hline & $\begin{array}{l}\text { City up to } 100,000 \\
\text { inhabitants }\end{array}$ & 442 & 18.6 & 5.4 & \\
\hline & $\begin{array}{l}\text { City between } 100,000 \text { and } \\
500,000 \text { inhabitants }\end{array}$ & 133 & 18.8 & 5.1 & \\
\hline & $\begin{array}{l}\text { City larger than 500,000 } \\
\text { inhabitants }\end{array}$ & 519 & 18.5 & 5.8 & \\
\hline \multirow{3}{*}{$\begin{array}{l}\text { Place of residence at the } \\
\text { time of the survey }\end{array}$} & Family home & 1465 & 18.4 & 5.6 & \multirow{3}{*}{$\begin{array}{c}\mathrm{F} \text { value }=0.18 \\
p \text { value }=0.831 \\
\eta^{2}=0.000\end{array}$} \\
\hline & Rented apartment & 427 & 18.5 & 5.6 & \\
\hline & Dormitory & 19 & 17.7 & 6.6 & \\
\hline \multirow{3}{*}{ Type of studies } & First-cycle studies & 1076 & 18.6 & 5.6 & \multirow{3}{*}{$\begin{array}{c}\mathrm{F} \text { value }=5.18 \\
p \text { value }=0.006 \\
\eta^{2}=0.006\end{array}$} \\
\hline & Second-cycle studies & 458 & 17.7 & 5.5 & \\
\hline & $\begin{array}{l}\text { Long-cycle master's } \\
\text { degree studies }\end{array}$ & 316 & 18.7 & 5.5 & \\
\hline \multirow{5}{*}{ Year of studies } & First & 827 & 18.5 & 5.6 & \multirow{5}{*}{$\begin{array}{c}\text { F value }=1.13 \\
p \text { value }=0.336 \\
\eta^{2}=0.002\end{array}$} \\
\hline & Second & 511 & 18.2 & 5.4 & \\
\hline & Third & 290 & 18.8 & 5.8 & \\
\hline & Fourth & 111 & 18.4 & 5.7 & \\
\hline & Fifth & 145 & 17.7 & 5.3 & \\
\hline \multirow{3}{*}{ Social status } & Low & 396 & 19.1 & 5.4 & \multirow{3}{*}{$\begin{array}{c}\text { F value }=6.23 \\
p \text { value }=0.002 \\
\eta^{2}=0.007\end{array}$} \\
\hline & Medium & 1059 & 18.3 & 5.6 & \\
\hline & High & 385 & 17.7 & 5.7 & \\
\hline \multirow{3}{*}{ Faith } & Believers & 1260 & 18.1 & 5.4 & \multirow{3}{*}{$\begin{array}{c}\mathrm{F} \text { value }=5.45 \\
p \text { value }=0.004 \\
\eta^{2}=0.006\end{array}$} \\
\hline & Non-believers & 322 & 18.8 & 5.8 & \\
\hline & Undecided & 329 & 19.1 & 5.7 & \\
\hline \multirow{3}{*}{ School grades } & Up to 3.5 & 200 & 19.1 & 5.6 & \multirow{3}{*}{$\begin{array}{c}\mathrm{F} \text { value }=2.30 \\
p \text { value }=0.100 \\
\eta^{2}=0.002\end{array}$} \\
\hline & From 3.51 to 4.5 & 1474 & 18.3 & 5.5 & \\
\hline & Higher than 4.51 & 211 & 18.7 & 6.0 & \\
\hline \multirow{3}{*}{ Educational burnout } & Low $(\leq 36)$ & 227 & 13.2 & 4.6 & \multirow{3}{*}{$\begin{array}{c}\mathrm{F} \text { value }=318.06 \\
p \text { value }=0.000 \\
\eta^{2}=0.254\end{array}$} \\
\hline & Medium (37-58) & 1112 & 17.6 & 4.9 & \\
\hline & High $(\geq 59)$ & 531 & 22.3 & 4.7 & \\
\hline \multirow{3}{*}{$\begin{array}{c}\text { Evaluation of distance } \\
\text { learning }\end{array}$} & Bad & 786 & 16.9 & 5.6 & \multirow{3}{*}{$\begin{array}{c}\mathrm{F} \text { value }=46.91 \\
p \text { value }=0.000 \\
\eta^{2}=0.047\end{array}$} \\
\hline & Average & 679 & 19.1 & 5.3 & \\
\hline & Good & 461 & 19.6 & 5.1 & \\
\hline \multirow{2}{*}{ Problem-focused strategy } & Yes & 783 & 18.1 & 5.8 & \multirow{2}{*}{$\begin{array}{c}\mathrm{F} \text { value }=2.58 \\
p \text { value }=0.133 \\
\eta^{2}=0.001\end{array}$} \\
\hline & No & 1144 & 18.5 & 5.4 & \\
\hline
\end{tabular}


Table 1. Cont.

\begin{tabular}{|c|c|c|c|c|c|}
\hline & & $\mathbf{n}$ & $\mathbf{M}$ & SD & \\
\hline \multirow{2}{*}{ Emotion-focused strategy } & Yes & 1528 & 21.2 & 5.8 & \multirow{2}{*}{$\begin{array}{c}\mathrm{F} \text { value }=136.00 \\
p \text { value }=0.000 \\
\eta^{2}=0.066\end{array}$} \\
\hline & No & 399 & 17.6 & 5.3 & \\
\hline \multirow{3}{*}{ Financial stress } & Yes & 895 & 19.3 & 5.6 & \multirow{3}{*}{$\begin{array}{c}\mathrm{F} \text { value }=28.35 \\
p \text { value }=0.000 \\
\eta^{2}=0.029\end{array}$} \\
\hline & No & 793 & 17.3 & 5.4 & \\
\hline & Don't know & 224 & 18.5 & 5.3 & \\
\hline \multirow{3}{*}{ Satisfaction with life } & Yes & 1428 & 17.3 & 5.3 & \multirow{3}{*}{$\begin{array}{c}\mathrm{F} \text { value }=118.52 \\
p \text { value }=0.000 \\
\eta^{2}=0.111\end{array}$} \\
\hline & No & 299 & 21.9 & 5.2 & \\
\hline & Don't know & 184 & 21.1 & 5.0 & \\
\hline \multirow{2}{*}{ Interest in the pandemic } & Yes & 1458 & 18.4 & 5.6 & \multirow{2}{*}{$\begin{array}{c}\mathrm{F} \text { value }=0.42 \\
p \text { value }=0.516 \\
\eta^{2}=0.000\end{array}$} \\
\hline & No & 455 & 18.2 & 5.4 & \\
\hline \multirow{4}{*}{ Fear of COVID-19 } & Yes, it poses a threat & 405 & 18.4 & 5.7 & \multirow{4}{*}{$\begin{array}{c}F \text { value }=5.11 \\
p \text { value }=0.002 \\
\eta^{2}=0.008\end{array}$} \\
\hline & Poses only a slight threat & 868 & 18.6 & 5.4 & \\
\hline & Does not pose a threat & 364 & 17.4 & 5.8 & \\
\hline & Hard to say & 276 & 18.9 & 5.4 & \\
\hline \multirow{3}{*}{ Evaluation of government } & Positive & 530 & 17.7 & 5.3 & \multirow{3}{*}{$\begin{array}{c}\mathrm{F} \text { value }=8.18 \\
p \text { value }=0.000 \\
\eta^{2}=0.010\end{array}$} \\
\hline & Negative & 534 & 19.1 & 5.8 & \\
\hline & Hard to say & 696 & 18.4 & 5.4 & \\
\hline
\end{tabular}

Table 2 presents the results of the hierarchical regression analysis which was used in order to investigate the relationship between socio-demographic variables, attitudes towards the pandemic, psychological variables, other variables describing the experience with distance education and the level of psychosomatic disorders. In the first stage, the socio-demographic variables were introduced, in the second stage, the variables measuring the attitudes towards the pandemic were applied, in the third stage, the psychological variables were introduced to the model, whereas in the fourth stage, the variables monitoring the educational burnout were included.

Table 2. Results of multiple regression analyses predicting the level of psychological distress.

\begin{tabular}{|c|c|c|c|c|c|c|c|c|}
\hline \multirow[b]{2}{*}{ Variables } & \multicolumn{2}{|c|}{ Model I } & \multicolumn{2}{|c|}{ Model II } & \multicolumn{2}{|c|}{ Model III } & \multicolumn{2}{|c|}{ Model IV } \\
\hline & $\beta$ & $p$ & $\beta$ & $p$ & $\beta$ & $p$ & $\beta$ & $p$ \\
\hline Gender & 0.150 & 0.000 & 0.142 & 0.000 & 0.123 & 0.000 & 0.092 & 0.000 \\
\hline Place of residence & 0.052 & 0.072 & 0.047 & 0.105 & 0.026 & 0.316 & 0.017 & 0.464 \\
\hline $\begin{array}{l}\text { Place of residence at the time of the } \\
\text { survey }\end{array}$ & 0.018 & 0.530 & 0.016 & 0.640 & 0.018 & 0.007 & 0.007 & 0.759 \\
\hline Faith & 0.077 & 0.003 & 0.077 & 0.003 & 0.022 & 0.374 & 0.019 & 0.369 \\
\hline University grades & 0.032 & 0.210 & 0.032 & 0.203 & 0.006 & 0.794 & 0.018 & 0.365 \\
\hline $\begin{array}{l}\text { Relative evaluation of one's financial } \\
\text { standing }\end{array}$ & 0.118 & 0.000 & 0.113 & 0.000 & 0.047 & 0.080 & 0.036 & 0.119 \\
\hline Type of studies & 0.036 & 0.158 & 0.038 & 0.134 & 0.017 & 0.470 & 0.001 & 0.816 \\
\hline Year of studies & 0.025 & 0.340 & 0.023 & 0.375 & 0.015 & 0.523 & 0.019 & 0.342 \\
\hline Social status & 0.028 & 0.338 & 0.030 & 0.303 & 0.036 & 0.178 & 0.028 & 0.222 \\
\hline $\begin{array}{l}\text { Interest in the information about } \\
\text { COVID-19 }\end{array}$ & & & 0.022 & 0.394 & 0.012 & 0.625 & 0.013 & 0.455 \\
\hline
\end{tabular}


Table 2. Cont.

\begin{tabular}{|c|c|c|c|c|c|c|c|c|}
\hline \multirow[b]{2}{*}{ Variables } & \multicolumn{2}{|c|}{ Model I } & \multicolumn{2}{|c|}{ Model II } & \multicolumn{2}{|c|}{ Model III } & \multicolumn{2}{|c|}{ Model IV } \\
\hline & $\beta$ & $p$ & $\beta$ & $p$ & $\beta$ & $p$ & $\beta$ & $p$ \\
\hline Fear of the disease & & & 0.019 & 0.473 & 0.037 & 0.120 & 0.013 & 0.531 \\
\hline Evaluation of government & & & 0.025 & 0.327 & 0.011 & 0.648 & 0.022 & 0.208 \\
\hline Probability of becoming infected & & & 0.060 & 0.022 & 0.039 & 0.099 & 0.043 & 0.047 \\
\hline Satisfaction with life & & & & & 0.267 & 0.000 & 0.155 & 0.000 \\
\hline Financial stress & & & & & 0.067 & 0.005 & 0.028 & 0.174 \\
\hline Problem-focused strategy & & & & & -0.071 & 0.004 & -0.073 & 0.001 \\
\hline Emotion-focused strategy & & & & & -0.266 & 0.000 & -0.151 & 0.000 \\
\hline Educational burnout & & & & & & & 0.505 & 0.000 \\
\hline Evaluation of distance learning & & & & & & & 0.038 & 0.087 \\
\hline $\mathrm{F}(p \leq 0.000)$ & \multicolumn{2}{|c|}{8.32} & \multicolumn{2}{|c|}{6.36} & \multicolumn{2}{|c|}{24.92} & \multicolumn{2}{|c|}{57.21} \\
\hline R square & \multicolumn{2}{|c|}{0.041} & \multicolumn{2}{|c|}{0.043} & \multicolumn{2}{|c|}{0.210} & \multicolumn{2}{|c|}{0.410} \\
\hline Standard error & \multicolumn{2}{|c|}{05.4} & \multicolumn{2}{|c|}{5.4} & \multicolumn{2}{|c|}{4.9} & \multicolumn{2}{|c|}{4.2} \\
\hline
\end{tabular}

The results of the hierarchical regression analysis indicate that demographic variables explain only $4 \%$ of the psychological discomfort variance. Females, people who evaluate their financial standing as bad, and non-believers experienced higher levels of stress.

The introduction of variables measuring the attitudes towards the pandemic failed to increase the level of explained variance. In the third stage, upon the introduction of psychological variables, the level of explained variance was $21 \%$. The change in the explained variance was statistically relevant. A significant change in corrected $\mathrm{R}^{2}$, (delta corrected $\mathrm{R}^{2}=0.167 ; \mathrm{F}$ change $\left.(4,1517)=80.923, p<0.000\right)$ was observed. In this model, the strongest predictor of psychosomatic disorders was the lack of satisfaction with life and an emotion-focused strategy for coping with stress. From the first model, only the gender remained statistically relevant.

In the fourth stage, upon the introduction of variables describing exhaustion with distance education, the explained variance factor was $41 \%$. The change in the explained variance was statistically relevant. A significant change in corrected $\mathrm{R}^{2}$, (delta corrected $\mathrm{R}^{2}$ $=0.199 ;$ F change $(2,1515)=259.462, p<0.000)$ was observed. In this model, the strongest predictor of health disorders was exhaustion from distance education. From the first model, only the gender remained statistically relevant. From the third model, the lack of satisfaction with life and the emotion-focused strategy were statistically relevant.

\section{Discussion}

The results of this research indicate that psychosomatic health problems are present among Polish students. Internalizing disorders occur as well. After four months of quarantine, almost $\frac{3}{4}$ of respondents displayed average and high levels of symptoms of internalizing disorders. In a similar study carried out among students in Wrocław, 77\% of the participants had psychopathological symptoms measured by the GHQ (28) [30]. This means that the quarantine, the lack of contact with peers and teachers, the stress occurring in their families and uncertainty imposed by the COVID-19 pandemic have a negative impact on the mental health of students in different cultures. This is supported by the results of the meta-analysis in which 706,415 students from all over the world participated. As a result, it was found that the pandemic negatively influenced the mental health of adolescents suffering from depression in 39\% of participants (95\% CI: $27-51 \%$ ) and anxiety in $36 \%$ of participants (95\% CI: $26-46 \%$ ) [31]. It should also be assumed that the pandemic could activate mechanisms leading to mental health disorders in people without mental health problems and aggravate the problem of young people who already had problems 
with mental health. According to WHO statistics, the global prevalence of depression in 2015 was $4.4 \%$, and the prevalence of anxiety was 3.6\% [32]. On the other hand, the results of comparative studies in the United States show that before the pandemic, among people aged 19-29 between 2018 and 2020, the percentage of moderate or serious distress increased from $26 \%$ to $82 \%$ [4]. The analyses conducted within this study also allow for the identification of the main sources of psychological distress among students during the lockdown. Educational burnout had the strongest impact on internalizing disorders. Social isolation, lower motivation, the lack of contact with peers and teachers, exhaustion from learning on the computer, and the lack of physical activity constitute the educational burnout syndrome. The above findings are observed in other studies [33,34]. A differing study, indicating a decrease in educational burnout among students during the quarantine, has also come to being [35].

Yet another risk factor of a bad psychosocial condition was the passive, emotionfocused strategy for coping with the pandemic-related stress [28]. The students who undertook strategies such as using psychoactive substances, sedatives, and passively observing events in the world have worse psychosomatic health. The confirmation of the above findings can be found in the works of other researchers [13]. A strong relationship between negative adaptive stress coping strategies and higher levels of anxiety, stress and depression is discussed therein. Negative strategies may result in the strengthening of the feeling of losing control over one's life and increase the sense of helplessness. In a situation such as a pandemic, such attitudes will have a negative impact on mental health.

Satisfaction with life had a positive impact on the students' mental health, which was indicated in other studies as well [36,37]. It may be assumed that psychological well-being is a deeper personality trait and constitutes protection from pandemic-related stress.

The results of this research confirm prior assumptions that young females are more likely to display mental disorders during the pandemic. This is also visible in longitudinal studies conducted during the pandemic in Poland. Over the course of five measurements, the levels of depression, anxiety and stress were significantly higher among female students [38]. Similar results were obtained in international studies of students, where statistically significantly higher scores on the Generalized Anxiety Disorder (GAD-7), Patient Health Questionnaire (PHQ-8), and Perceived Stress Scale (PSS-10) were observed in females students [39]. In the United States, female students were significantly more likely to report anxiety and PTSD risk symptoms [40].

The results of this research failed to confirm the relationship between the year of studies, the type of studies/major and an increase in psychosomatic disorders. It is in contradiction to the results of the meta-analysis [41]. Researchers also point out that the risk factors for mental disorders among students include the process of switching from education to the labor market. Changing a known environment and social role is stressful under normal conditions [42]. It would seem that the pandemic increased the scope of risk and uncertainty in the labor market, primarily among young people, because, as research shows, they lost their jobs more often and had a greater problem with employment during the pandemic [22].

Senior students have a similar level of health disorders as students who have just taken up their studies. Furthermore, the results of this research indicate that students returning to their family homes and living with their parents did not result in mental discomfort. This may mean that living with their families did not result in the occurrence of domestic violence, which is also indicated by a range of studies $[43,44]$. The conducted study indicates that loneliness occurring during distance education has a much stronger impact on young people's mental health. This is confirmed by the results of the metaanalysis carried out during the pandemic. Importantly, mental health disorders were more closely correlated with the duration of loneliness than with its subjective strength [45]. This means that subsequent lockdowns may aggravate the emerging mental health problem of adolescents. 


\section{Conclusions}

This study, conducted among students in a large academic city, indicates that more than half of the respondents report psychosomatic symptoms. Educational burnout was found to be the main risk factor of poor mental health. Therefore, it shall be assumed that being overloaded with distance education is one of the threats to the students' mental health. This could be observed by the end of the semester during the first wave of the pandemic in Poland.

In connection with the emerging psychosomatic ailments, it should be assumed that attention, concentration, thought processes and memory will be negatively affected. This will translate into a decline in learning results. Thus, students may become aware of the decline in their educational and life chances. Consequently, this will lead to further negative psychosocial effects that will hinder adaptation to the conditions created by pandemics and present in the post-pandemic world. It is worth adding that this is a particularly dangerous situation for the society, because students are a factor which revitalizes society and are the main force of its development. The main message from this research is also the need to provide psychological support at universities and in the students' place of residence. The results of this research clearly indicate that the authorities of countries, local governments and universities should immediately start providing psychological help for young people. The knowledge, obtained from many studies, that indicates how to improve the mental condition of students and how to minimize risk factors should be used. The university authorities should enable the use of online psychotherapy. University authorities should also strive to improve their well-being and teach students effective strategies for coping with stress.

The scale of problems caused by remote education and the pandemic also shows the need for in-depth quantitative and qualitative research on young people. Through systematic observation and triangulation of methods, it is possible to determine the psychosocial effects of the lockdown and distance education and to check, for example, through a case study, what are the effective ways of helping students with mental disorders. Evidencebased knowledge would create a catalog of good practices and improve student interventions.

\section{Limitations}

The present study has certain limitations. Since the data were collected from participants on a voluntary basis through an on-line application, generalizations should be made cautiously. It was also difficult to determine the rate of return of completed interviews due to a link with the survey being sent to the respondents. Another limitation is the cross-sectional nature of this study. The implemented research plan prevents us from drawing causal conclusions regarding the relationship between the impact of the pandemic on the variables measured in the respondents. Finally, it is worth adding that one of the authors is an academic teacher at the university where the research was conducted, and this could somehow affect the answers obtained from the students.

Author Contributions: P.D. Conceptualization, Methodology, Data collection, Literature, Discussion, Writing-Original draft preparation, Writing-Reviewing and Editing. D.L. Cooperation, Assistance, Literature, Discussion, Conclusions, Limitations, Translation, Writing-Reviewing and Editing. All authors have read and agreed to the published version of the manuscript.

Funding: This research received no specific grant from any research funding agency.

Institutional Review Board Statement: The authors assert that all procedures contributing to this work comply with the ethical standards of the relevant national and institutional committees on human experimentation and with the Helsinki Declaration of 1975, as revised in 2008.

Informed Consent Statement: Informed consent was obtained from all subjects involved in the study.

Data Availability Statement: Data available on request from the corresponding author. 
Acknowledgments: The authors would like to thank all the individuals who served as the research participants.

Conflicts of Interest: The authors declared no potential conflict of interest with respect to the research, authorship, and/or publication of this article.

\section{References}

1. Saunders, M.J.; Evans, C.A. COVID-19, tuberculosis and poverty: Preventing a perfect storm. Eur. Respir. J. 2020, 56, 2001348. [CrossRef]

2. Global Education Coalition Progress Report (March 2021). 2021. Available online: https://en.unesco.org/covid19/ educationresponse/globalcoalition (accessed on 26 March 2020).

3. Golberstein, E.; Wen, H.; Miller, B.F. Coronavirus Disease 2019 (COVID-19) and Mental Health for Children and Adolescents. JAMA Pediatr. 2020, 174, 819-820. [CrossRef]

4. Twenge, J.; Joiner, T. Mental distress among U.S. adults during the COVID-19 pandemic. J. Clin. Psychol. 2020, 76, 2170-2182. [CrossRef]

5. Gray, N.S.; O'Connor, C.; Knowles, J.; Pink, J.; Simkiss, N.J.; Williams, S.D.; Snowden, R.J. The Influence of the COVID-19 Pandemic on Mental Well-Being and Psychological Distress: Impact Upon a Single Country. Front. Psychiatry 2020, $11,594115$. [CrossRef]

6. von Soest, T.V.; Bakken, A.; Pedersen, W.; Sletten, M.A. Livstilfredshet blant ungdom før og under covid-19-pandemien [Life satisfaction among adolescents before and during the COVID-19 pandemic]. Tidsskr Nor Laegeforen 2020, 140. [CrossRef]

7. Wang, X.; Hegde, S.; Son, C.; Keller, B.; Smith, A.; Sasangohar, F. Investigating Mental Health of US College Students during the COVID-19 Pandemic: Cross-Sectional Survey Study. J. Med. Internet Res. 2020, 22, e22817. [CrossRef]

8. Li, Y.; Zhao, J.; Ma, Z.; McReynolds, L.S.; Lin, D.; Chen, Z.; Wang, T.; Wang, D.; Zhang, Y.; Zhang, J.; et al. Mental Health among College Students During the COVID-19 Pandemic in China: A 2-Wave Longitudinal Survey. J. Affect. Disord. 2021, 281, 597-604. [CrossRef] [PubMed]

9. Essadek, A.; Rabeyron, T. Mental health of French students during the Covid-19 pandemic. J. Affect. Disord. 2020, 277, 392-393. [CrossRef] [PubMed]

10. Caffo, E.; Scandroglio, F.; Asta, L. Debate: COVID-19 and psychological wellbeing of children and adolescents in Italy. Child Adolesc. Ment. Health 2020, 25, 167-168. [CrossRef]

11. Zhou, S.J.; Zhang, L.G.; Wang, L.L.; Guo, Z.C.; Wang, J.Q.; Chen, J.C.; Chen, J.X. Prevalence and socio-demographic correlates of psychological health problems in Chinese adolescents during the outbreak of COVID-19. Eur. Child Adolesc. Psychiatry 2020, 29, 749-758. [CrossRef] [PubMed]

12. Qi, M.; Zhou, S.J.; Guo, Z.C.; Zhang, L.G.; Min, H.J.; Li, X.M.; Chen, J.X. The Effect of Social Support on Mental Health in Chinese Adolescents during the Outbreak of COVID-19. J. Adolesc. Health 2020, 67, 514-518. [CrossRef] [PubMed]

13. Zhang, C.; Ye, M.; Fu, Y.; Yang, M.; Luo, F.; Yuan, J.; Tao, Q. The Psychological Impact of the COVID-19 Pandemic on Teenagers in China. J. Adolesc. Health 2020, 67, 747-755. [CrossRef] [PubMed]

14. Scovil, J. Samopoczucie Polaków w Roku 2020 [The Well-Being of Poles in 2020]. Available online: https://www.cbos.pl/ SPISKOM.POL/2021/K_001_21.PDF (accessed on 30 March 2020).

15. de Figueiredo, C.S.; Sandre, P.C.; Portugal, L.; Mázala-de-Oliveira, T.; da Silva Chagas, L.; Raony, Í.; Ferreira, E.S.; Giestal-deAraujo, E.; Dos Santos, A.A.; Bomfim, P.O. COVID-19 pandemic impact on children and adolescents' mental health: Biological, environmental, and social factors. Prog. Neuro-Psychopharmacol. Biol. Psychiatry 2020, 106, 110171. [CrossRef] [PubMed]

16. Panda, P.K.; Gupta, J.; Chowdhury, S.R.; Kumar, R.; Meena, A.K.; Madaan, P.; Sharawat, I.K.; Gulati, S. Psychological and behavioral impact of lockdown and quarantine measures for COVID-19 pandemic on children, adolescents and caregivers: A systematic review and meta-analysis. J. Trop. Pediatr. 2021, 67, fmaa122. [CrossRef]

17. Woźniak-Prus, M.; Gambinb, M.; Cudoc, A. Nastolatkowie Wobec Pandemii [Teenagers towards the Pandemic]. Available online: https:/ / covid.psych.uw.edu.pl/wp-content/uploads/sites/50/2021/03/Raport_nastolatkowie_wobec_pandemii.pdf (accessed on 24 September 2021).

18. Koronawirus w Polsce: W Październiku Trzy Razy Więcej Przypadków niż do Września [Coronavirus in Poland: Three Times More Cases in October than until September]. 2020. Available online: https:/ /www.rp.pl/Covid-19/201109984-Koronawirus-wPolsce-W-pazdzierniku-trzy-razy-wiecej-przypadkow-niz-do-wrzesnia.html (accessed on 24 September 2021).

19. Barański, K.; Brożek, G.; Kowalska, M.; Kaleta-Pilarska, A.; Zejda, J.E. Impact of COVID-19 Pandemic on Total Mortality in Poland. Int. J. Environ. Res. Public Health 2021, 18, 4388. [CrossRef] [PubMed]

20. Boguszewski, R.; Makowska, M.; Podkowińska, M.A. Typology of Poles' Attitudes toward COVID-19 during the First Wave of the Pandemic. Int. J. Environ. Res. Public Health 2021, 18, 2002. [CrossRef]

21. Epidemia Koronawirusa a Sytuacja Zawodowa Polaków [Epidemic Coronavirus and the Professional Situation of Poles]. CBOS: Warszawa, Poland, 2020. Available online: https:/ / www.cbos.pl/SPISKOM.POL/2020/K_070_20.PDF (accessed on 24 September 2021).

22. Kochhar, R. Unemployment Rose Higher in Three Months of COVID-19 than It Did in Two Years of the Great Recession. 12 June 2020. Available online: https://www.pewresearch.org/fact-tank/2020/06/11/unemployment-rose-higher-in-three-monthsof-covid-19-than-it-did-in-two-years-of-the-great-recession/ (accessed on 24 September 2021). 
23. Inchley, J.; Currie, D.; Budisavljevic, S.; Torsheim, T.; Jåstad, A.; Cosma, A.; Kelly, C.; Arnarsson, A.M. Spotlight on Adolescent Health and Well-Being. Volume 1. World Health Organization, 2020. Available online: http://www.hbsc.org/publications/ international (accessed on 23 March 2020).

24. Mazur, J. Subiektywna ocean zdrowia [Subjective assessment of health]. In Zdrowie Uczniów w Szkole w 2018 r. na tle Nowego Modelu Badan HBSC [The Health of Adolescents in 2018 r. in the Light of the New Model of the HBSC Research]; Mazur, J., Małkowska-Szkutnik, A., Eds.; IMiD: Warszawa, Poland, 2020; pp. 59-70.

25. Yang, H.J.; Frac, C.K. An investigation the factors affecting MIS student burnout in technical-vocational college. Comput. Hum. Behav. 2005, 21, 917-932. [CrossRef]

26. Santinello, M.; Altonoè, G. Il Link Burnout Questionnaire. In Manuale dell'LBQ-Link Burnout Questionnaire [The manual of LBQ_Link Burnout Questionnaire]; Santinello, M., Ed.; Organizzazioni Speciali: Firenze, Italy, 2007; pp. 12-19.

27. Jaworowska, A. Kwestionariusz Wypalenia Zawodowego Massimo Santinello; Polska Normalizacja; Pracownia Testów Psychologicznych Polskiego Towarzystwa Psychologicznego: Warszawa, Poland, 2014.

28. Lazarus, R.S.; Folkman, S. Stress, Appraisal, and Coping; Springer: New York, NY, USA, 1984.

29. Czapiński, J. Diagnoza Społeczna 2015. [SOCIAL DIAGNOSIS 2015]. 2015. Available online: http://www.diagnoza.com/pliki/ raporty/Diagnoza_raport_2015.pdf (accessed on 25 March 2020).

30. Rogowska, A.M.; Kuśnierz, C.; Bokszczanin, A. Examining Anxiety, Life Satisfaction, General Health, Stress and Coping Styles During COVID-19 Pandemic in Polish Sample of University Students. Psychol. Res. Behav. Manag. 2020, 13, 797-811. [CrossRef]

31. Li, Y.; Wang, A.; Wu, Y.; Han, N.; Huang, H. Impact of the COVID-19 Pandemic on the Mental Health of College Students: A Systematic Review and Meta-Analysis. Front. Psychol. 2021, 12, 669119. [CrossRef]

32. World Health Organization. Depression and Other Common Mental Disorders: Global Health Estimates; World Health Organization: Geneva, Switzerland, 2017.

33. Najmul, H.; Yukun, B. Impact of "e-Learning crack-up" perception on psychological distress among college students during COVID-19 pandemic: A mediating role of "fear of academic year loss. Child. Youth Serv. Rev. 2020, 118, 105355. [CrossRef]

34. Zis, P.; Artemiadis, A.; Bargiotas, P.; Nteveros, A.; Hadjigeorgiou, G.M. Medical Studies during the COVID-19 Pandemic: The Impact of Digital Learning on Medical Students' Burnout and Mental Health. Int. J. Environ. Res. Public Health 2021, 18, 349. [CrossRef]

35. Bolatov, A.K.; Seisembekov, T.Z.; Askarova, A.Z.; Baikanova, R.K.; Smailova, D.S.; Fabbro, E. Online-Learning due to COVID-19 Improved Mental Health Among Medical Students. Med. Sci. Educ. 2020, 31, 183-192. [CrossRef]

36. Fergusson, D.M.; McLeod, G.F.H.; Horwood, L.J.; Swain, N.R.; Chapple, S.; Poulton, R. Life satisfaction and mental health problems (18 to 35 years). Psychol. Med. 2015, 45, 2427-2436. [CrossRef] [PubMed]

37. Cong, D.D. The impact of fear and anxiety of Covid-19 on life satisfaction: Psychological dis-tress and sleep disturbance as mediators. Personal. Individ. Differ. 2021, 178, 110869. [CrossRef]

38. Debowska, A.; Horeczy, B.; Boduszek, D.; Dolinski, D. A repeated cross-sectional survey assessing university students' stress, depression, anxiety, and suicidality in the early stages of the COVID-19 pandemic in Poland. Psychol. Med. 2020, 2, 1-4. [CrossRef] [PubMed]

39. Ochnik, D.; Rogowska, A.M.; Kuśnierz, C.; Jakubiak, M.; Schütz, A.; Held, M.J.; Arzenšek, A.; Benatov, J.; Berger, R.; Korchagina, E.V.; et al. Mental health prevalence and predictors among university students in nine countries during the COVID-19 pandemic: A cross-national study. Sci. Rep. 2021, 11, 18644. [CrossRef] [PubMed]

40. Lee, C.M.; Juarez, M.; Rae, G.; Jones, L.; Rodriguez, R.M.; Davis, J.A.; Boysen-Osborn, M.; Kashima, K.J.; Krane, N.K.; Kman, N.; et al. Anxiety, PTSD, and stressors in medical students during the initial peak of the COVID-19 pandemic. PLoS ONE 2021, 16, e0255013. [CrossRef]

41. Deng, J.; Zhou, F.; Hou, W.; Silver, Z.; Wong, C.Y.; Chang, O.; Drakos, A.; Zuo, Q.K.; Huang, E. The prevalence of depressive symptoms, anxiety symptoms and sleep disturbance in higher education students during the COVID-19 pandemic: A systematic review and metanalysis. Psychiatry Res. 2021, 301, 113863. [CrossRef]

42. Andrews, G.; Basu, A.; Cuijpers, P.; Craske, M.G.; McEvoy, P.; English, C.L.; Newby, J.M. Computer therapy for the anxiety and depression disorders is effective, acceptable and practical health care: An updated meta-analysis. J. Anxiety Disord. 2018, 55, 70-78. [CrossRef]

43. Leslie, E.; Wilson, R. Sheltering in place and domestic violence: Evidence from calls for service during COVID-19. J. Public Econ. 2020, 189, 104241. [CrossRef]

44. Campbell, A.M. An Increasing Risk of Family Violence during the Covid-19 Pandemic: Strengthening Community Collaborations to Save Lives. Forensic Sci. Int. Rep. 2020, 2, 100089. [CrossRef]

45. Loades, M.E.; Chatburn, E.; Higson-Sweeney, N.; Reynolds, S.; Shafran, R.; Brigden, A.; Linney, C.; McManus, M.N.; Borwick, C.; Crawley, E. Rapid Systematic Review: The Impact of Social Isolation and Loneliness on the Mental Health of Children and Adolescents in the Context of COVID-19. J. Am. Acad. Child Adolesc. Psychiatry 2020, 59, 1218-1239.e3. [CrossRef] [PubMed] 